
ISSN : 2615-1995, E-ISSN : 2615-0654

J. Madani., Vol. 2, No. 2, September 2019 (270 - 288)

C2018 Lembaga Kajian Demokrasi

MADANI

dan Pemberdayaan Masyarakat (LKD-PM)

\title{
Analisis Rasio Aktivitas dan Rasio Rentabilitas Sebagai Alat Ukur Penilaian Kinerja Keuangan pada PT Telekomunikasi Indonesia (Persero), Tbk
}

\author{
Sutiman \\ Fakultas Ekonomi, Universitas Pamulang \\ soetiman2014@gmail.com
}

\begin{abstract}
Abstrak
Tujuan penelitian untuk mengetahui rasio aktivitas dan rasio rentabilitas yang dapat dijadikan sebagai alat ukur kinerja keuangan PT. Telekomunikasi Indonesia (Persero) Tbk. Dengan menggunakan alat ukur Analisa Rasio Aktivitas dan Rasio Rentabilitas. Penelitian dilakukan di PT. Telekomunikasi Indonesia (Persero) Tbk tahun 2007-2015 yang terdaftar di Bursa Efek Indonesia (BEI). Metode analisis data adalah metode deskriptif analisis, yaitu suatu metode penelitian yang bertujuan menggambarkan keadaan objek yang diteliti berdasarkan fakta-fakta yang ada dengan cara mengumpulkan, mengolah, menyajikan serta menganalisis berbagai data yang ditemukan dan membandingkannya dengan teori yang ada, kemudian dianalisis penerapannya dalam praktek sehingga dapat ditarik kesimpulan. Hasil penelitian: Rasio Aktivitas yang terdiri atas fixed assets turnover dan total assets turnover mengalami ketidakstabilan yang artinya adanya peningkatan dan penurunan di setiap tahunnya. Sedangkan rata-rata fixed assets turnover sebesar 0,86 Kali $(<5$ Kali), dan dari total assets turnover yaitu sebesar 0,67 Kali $(<2$ Kali), Rasio Rentabilitas yang terdiri atas return on investment dan return on equity cenderung mengalami ketidakstabilan yang artinya adanya peningkatan dan penurunan di setiap tahunnya. Berdasarkan total rata-rata return on investment sebesar $16.19 \%(<30 \%)$ dan total rata-rata return on equity sebesar $32.50 \%$ (<40\%). Hasil analisis penilaian kinerja dari aspek keuangan untuk rasio aktivitas dan rasio rentabilitas dapat dikatakan kurang baik. Terlihat dari aktivitas perusahaan rata-rata fixed assets turnover 0,86 Kali ( $<5$ Kali standar industri) dan total assets turnover 0,67 Kali $(<2$ Kali standar industri) dan return on investment $16.19 \%$ ( $<30 \%$ standar industri) dan return on equty $32.50 \%$ $(<40 \%$ standar industri).
\end{abstract}

Kata Kunci : Aktivitas, Rentabilitas, Penilaian, Kinerja, Keuangan

\begin{abstract}
The purpose of this study is to determine the activity ratio and profitability ratio that can be used as a measure of financial good or bad and financial performance at PT. Telekomunikasi Indonesia (Persero) Tbk. By using a measuring instrument Activity Ratio Analysis and Rentability Ratio. The research was conducted at PT. Telekomunikasi Indonesia (Persero) Tbk in 2007-2015 which is listed on the Indonesia Stock Exchange (IDX). The method of data analysis is descriptive analysis method, which is a research method that aims to describe the state of the object under study based on existing facts by collecting, processing, presenting and analyzing various data found and comparing it with existing theories, then analyzing its application in practice so that conclusions can be drawn. Research results: Activity ratios consisting of fixed assets turnover and total assets turnover experience instability which means there is an increase and decrease in each year. While the average fixed assets turnover is 0.86 times ( $<5$ times), and from total assets turnover which is equal to 0.67 times $(<2$ times), the profitability ratio consisting of return on investment and return on equity tends to experience instability which means there is an increase and a decrease in each year Based on the total average return on
\end{abstract}


investment of $16.19 \%(<30 \%)$ and the total average return on equity of $32.50 \%(<40 \%)$. The results of the analysis of the performance evaluation of the financial aspects for activity ratios and profitability ratios can be said to be poor. Can be seen from the average company activity fixed assets turnover 0.86 times ( $<5$ times industry standard) and total assets turnover 0.67 times ( $<2$ times industry standard) and return on investment $16.19 \%(<30 \%$ industry standard) and return on equty $32.50 \%$ ( $<40 \%$ industry standard).

Keywords : Activity, Rentability, Assessment, Performanc, Finance

\section{PENDAHULUAN}

\section{Latar Belakang}

Pada perkembangan era ekonomi saat ini, setiap perusahaan didirikan dengan harapan bahwa perusahaan tersebut dapat mempertahankan kelangsungan usahanya, berkembang dengan pesat dan dapat eksis untuk jangka waktu yang panjang. Perusahaan dituntut untuk dapat mengelola fungsi-fungsi yang penting secara efektif dan efisien, sehingga perusahaan bisa lebih profesional terhadap kinerja keuangan. Perusahaan juga dituntut harus memiliki laporan keuangan yang baik serta dasar yang kuat dalam melaksanakan opersionalnya dalam rangka memaksimalkan laba.

Berdirinya sebuah perusahaan harus memiliki tujuan yang jelas. Ada beberapa hal yang mengemukakan tujuan dari berdirinya sebuah perusahaan. Tujuan yang pertama adalah untuk mencapai keuntungan maksimal. Tujuan yang kedua adalah ingin memakmurkan pemilik perusahaan atau para pemilik saham. Sedangkan tujuan perusahaan yang ketiga adalah memaksimalkan nilai perusahaan yang tercermin pada harga sahamnya. Ketiga tujuan perusahaan tersebut sebenarnya secara substansial tidak banyak berbeda, hanya penekanan yang ingin dicapai oleh masing-masing perusahaan berbeda antara yang satu dengan yang lainnya. (Agus Harjito dan Martono, 2014:25).

Menurut Warsidi \& Bambang dalam Fahmi (2013:87), Analisis Rasio adalah instrumen analisis prestasi dari perusahaan yang menjelaskan berbagai hubungan dan indikator keuangan yang ditujukan untuk menunjukkan perubahan dalam kondisi keuangan atau prestasi operasi di masa lalu dan membantu menggambarkan trend pola perubahan tersebut, untuk kemudian menunjukkan risiko dan peluang yang melekat pada perusahaan yang bersangkutanAnalisis rasio merupakan bentuk atau cara umum yang digunakan dalam analisis laporan keuangan dengan kata lain di antara alat-alat analisis yang selalu digunakan untuk mengukur kekuatan atau kelemahan suatu perusahaan di bidang keuangan adalah analisis rasio keuangan (finance ratio analysis).

"Tujuan dari analsis rasio adalah untuk membantu manajer finansial memahami apa yang perlu dilakukan oleh perusahaan, berdasarkan informasi yang tersedia dan sifat terbatas". (dalam Keown dkk, 2010:60). Analisis rasio pada dasarnya tidak hanya berguna bagi kepentingan internal perusahaan saja melainkan juga pihak luar dan ini berbeda menurut kepentingan khusus dari analisis atau pihak yang berkepentingan.

Rasio aktivitas merupakan rasio yang digunakan untuk mengukur efektivitas perusahaan dalam menggunakan aktiva yang dimilikinya atau rasio-rasio yang digunakan untuk mengukur tingkat efisiensi pemanfaatan sumber daya perusahaan berdasarkan dana yang dikelola atau rasio untuk menilai kemampuan perusahaan dalam melaksanakan aktivitas sehari-hari. (Kasmir, 2012:172).

Rasio rentabilitas atau rasio profitabilitas merupakan rasio yang digunakan untuk mengukur profit yang diperoleh dari modal untuk operasional perusahaan atau mengukur kemampuan perusahaan untuk memperoleh keuntungan. (Munawir, 2014:86)

Kinerja keuangan adalah suatu analisa yang digunakan untuk melihat sejauh mana suatu perusahaan telah melaksanakan dengan menggunakan aturan-aturan pelaksanaan keuangan secara baik dan benar seperti dengan membuat suatu laporan keuangan yang telah memenuhi standar SAK (Standar Akuntansi Keuangan) atau 


\section{GAAP (General Acepted Accounting Principle)} dan lainnya.

Mengingat pentingnya analisis rasio keuangan bagi kelangsungan perkembangan perusahaan. Kinerja keuangan adalah suatu analisis yang dilakukan untuk melihat sejauh mana suatu perusahaan telah melaksanakan dengan menggunakan aturan-aturan pelaksanaan keuangan secara baik dan teratur. (Fahmi, 2011:2)". Kinerja keuangan adalah rangkaian aktivitas keuangan pada suatu periode tertentu yang dilaporkan dalam laporan keuangan diantaranya laporan laba rugi dan neraca". (Gitosudarmo dan Basri, 2010:25).

Dalam hubungannya dengan penilaian kinerja keuangan perusahaan, tingkat kesehatan perusahaan bagi para pemegang saham sangat berkepentingan untuk mengetahui kondisi sebenarnya suatu perusahaan, agar modal yang diinvestasikan cukup aman dan mendapatkan tingkat hasil pengembalian (rate of return) yang menguntungkan dari investasi yang ditanamkannya. Bagi pihak manajemen perusahaan, penilaian kinerja ini akan sangat mempengaruhi dalam penyusunan rencana usaha perusahaan yang akan diambil untuk masa yang akan datang demi kelangsungan hidup perusahaan. Dalam konteks manajemen keuangan, analisis tersebut dikenal dengan analisis rasio keuangan. Analisis rasio ini berguna untuk membandingkan kinerja perusahaan yang satu dengan perusahaan lain atau membandingkan kinerja satu perusahaan pada tahun ini dengan ta- hun yang lainnya.

Dari diagram dibawah dapat dilihat dari perkembangan rasio aktivitas yang diukur dengan fixed assets turnover dan total assets turnover serta perkembangan rasio rentabilitas yang diukur dengan return on investment dan return on equity memperlihatkan bahwa ada kemampuan perolehan yang naik turun. Pada tahun 2007 Fixed Assets Turnover dan Total Assets Turnover mengalami kenaikan dari tahun sebelumnya yaitu tahun 2006.

Hal ini menunjukkan bahwa terdapat hasil penjualan, laba bersih sesudah bunga dan pajak, total aset dan total ekuitas setiap tahunnya sangat signifikan sekali tidak terlalu meningkat dan tidak terlalu menurun drastis.

Analisis yang akan dilakukan pada laporan keuangan PT. Telekomunikasi Indonesia (Persero) Tbk tahun 2007-2015 ditunjukan penulis agar dapat mengevaluasi dan mengetahui bagaimana aktivitas perusahaan selama tahun 20072015. Sehingga penulis dapat mengetahui aktivitas-aktivitas perusahaan dilihat dari kinerja keuangannya, kelemahan-kelemahan aktivitas kinerja keuangan perusahaan, kebijakan-kebijakan perusahaan, dan berupaya memberikan kesimpulan dan saran dalam memperbaiki kinerja keuangannya di tahun berikutnya.

Berdasarkan hal tersebut, penulis tertarik untuk melakukan penelitian terhadap rasio keuangan dengan kinerja keuangan perusahaan, karena penulis ingin mengetahui analisis rasio keuangan yang digunakan sebagai penilaian ki-

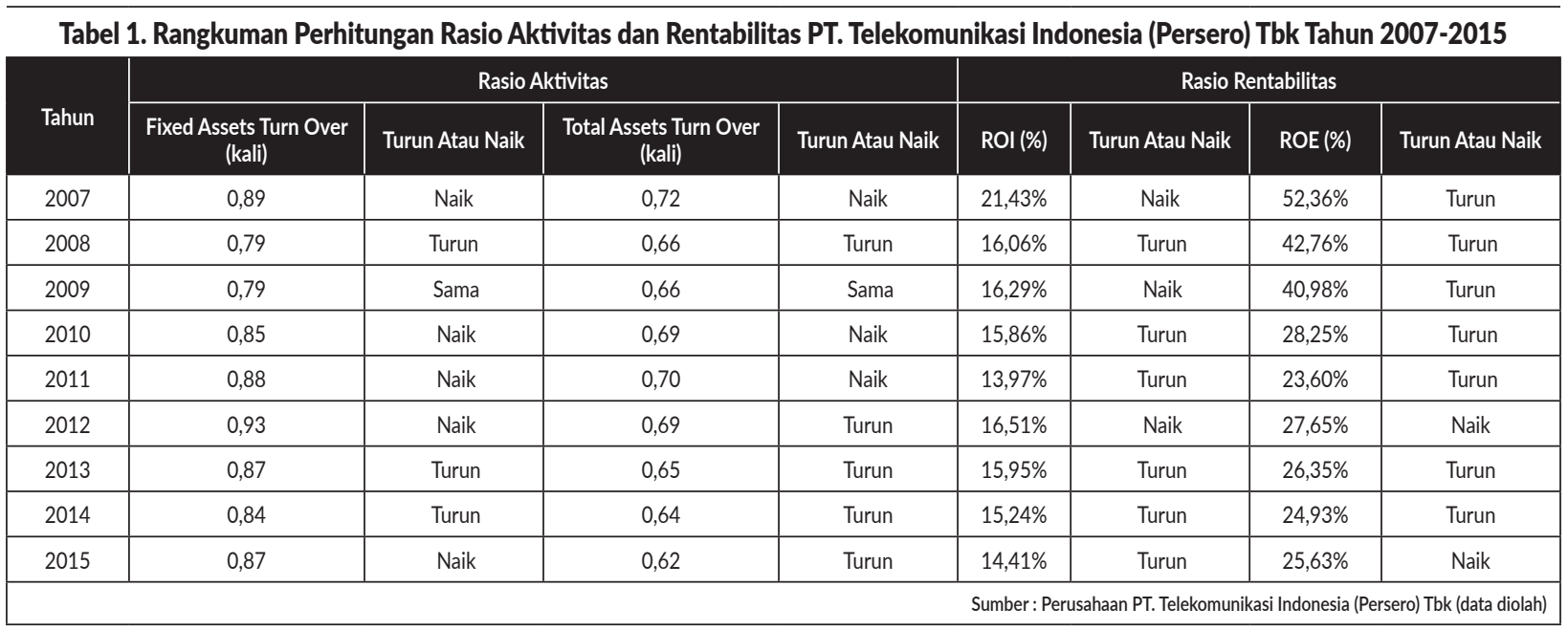


nerja keuangan PT. Telekomunikasi Indonesia (Persero) Tbk.

\section{Pembatasan Masalah}

Dalam penyusunan skripsi ini agar dalam pembahasan nanti tidak terlalu meluas, maka penulis membuat batasan-batasan permasalahan. Pembatasan masalah yang akan penulis sajikan dalam skripsi adalah:

1. Rasio keuangan yang digunakan dalam penelitian adalah:

a. Rasio aktivitas yang digunakan hanya alat ukur fixed assets turnover dan total assets turnover.

b. Rasio rentabilitas yang digunakan hanya alat ukur return on investment dan return on equity.

2. Kinerja keuangan adalah suatu analisis yang dilakukan untuk melihat sejauh mana suatu perusahaan telah melaksanakan dengan menggunakan aturan-aturan pelaksanaan keuangan secara baik dan benar. (Irham Fahmi, 2012:2)

3. Objek penelitian dilakukan PT. Telekomunikasi Indonesia (Persero) Tbk yang beralamat di Jalan Jenderal Sudirman Kav 52-53, Jakarta Selatan 12190, Indonesia, telp. (021) 5150515.

4. Data yang diteliti adalah laporan keuangan PT. Telekomunikasi Indonesia (Persero) Tbk tahun 2007-2015.

\section{Perumusan Masalah}

Berdasarkan latar belakang tersebut di atas maka penulis mencoba mengemukakan perumusan masalah sebagai berikut:

1. Bagaimana rasio aktivitas pada PT. Telekomunikasi Indonesia (Persero) Tbk selama periode tahun 2007-2015?

2. Bagaimana rasio rentabilitas pada PT. Telekomunikasi Indonesia (Persero) Tbk selama periode tahun 2007-2015?

3. Bagaimana kinerja keuangan di dalam PT. Telekomunikasi Indonesia (Persero) Tbk jika ditinjau dari rasio aktivitas dan rasio rentabilitasnya selama periode 2007-2015?

\section{Kajian Teori}

Analisis Rasio Keuangan

\section{Pengertian Rasio Keuangan}

Analisa rasio seperti halnya merupakan penganalisa yang harus mampu untuk menyesuaikan faktor-faktor yang ada pada periode waktu ini dengan faktor-faktor dimasa yang akan datang sehingga dapat mempengaruhi posisi keuangan atau hasil operasi perusahaan yang bersangkutan.

Menurut Kasmir (2012:93) Rasio Keuangan merupakan kegiatan membandingkan angka-angka yang ada dalam laporan keuangan dengan cara membagi satu angka dengan angka lainnya.

Menurut Sofyan Syafri Harahap (2015:297) Rasio Keuangan adalah angka yang diperoleh dari hasil perbandingan dari satu pos laporan keuangan dengan pos lainnya yang mempunyai hubungan yang relevan dan signifikan (berarti).

Jadi, dari definisi-definisi diatas dapat disimpulkan analisis rasio keuangan adalah membandingkan angka-angka yang ada dalam laporan keuangan untuk mengetahui posisi keuangan suatu perusahaan serta menilai kinerja manajemen dalam suatu periode tertentu.

Menurut Bambang Riyanto (2010:329), dalam mengadakan analisis rasio keuangan pada dasarnya dapat melakukannya dengan 2 macam cara pembandingan, yaitu:

a) Membandingkan rasio sekarang (present ratio) dengan rasio-rasio dari waktuwaktu yang lalu (ratio historis) atau dengan rasio-rasio yang diperkirakan untuk waktu-waktu yang akan datang dari perusahaan yang sama. Dengan cara membandingkan ini akan dapat diketahui perusahaan-perusahaan dari rasio tersebut maka dapatlah diambil kesimpulan mengenai tendesi atau kecenderungan keadaan keuangan serta hasil operasi perusahaan yang bersangkutan.

b) Membandingkan rasio-rasio dari suatu perusahaan dengan rasio-rasio semacam 
dari perusahaan lain yang sejenis atau industri (rasio industri/rasio standar) untuk waktu yang sama. Dengan cara ini akan dapat diketahui apakah perusahaan yang bersangkutan dalam aspek keuangan tertentu berada diatas ratarata industri, berada pada rata-rata atau terletak dibawah rata-rata industri.

\section{Tujuan dan Manfaat Analisis Rasio Keuangan}

Menurut Munawir (2014:65), tujuan dari analisis rasio keuangan adalah untuk dapat menentukan tingkat likuiditas, solvabilitas, keefektifan operasi serta derajat keuntungan suatu perusahaan. Analisis rasio seperti halnya alat-alat analisis harus mampu menyelesaikan faktor-faktor yang ada pada periode atau waktu tertentu, dengan faktorfaktor dimasa akan datang yang mungkin mempengaruhi posisi keuangan atau hasil operasi perusahaan yang bersangkutan. Dari hasil analisis rasio keuangan maka perusahaan dapat mengetahui kondisi keuangan apakah perusahaan tersebut akan menguntungkan apabila sahamnya dibeli.

Adapun manfaat analisis rasio keuangan menurut Irham Fahmi (2012:51) adalah sebagai berikut:

a. Analisis rasio keuangan sangat bermanfaat untuk dijadikan sebagai alat menilai kinerja dan prestasi perusahaan.

b. Analisis rasio keuangan sangat bermanfaat bagi pihak manajemen sebagai rujukan untuk membuat perencanaan.

c. Analisis rasio keuangan dapat dijadikan sebagai alat untuk mengevaluasi kondisi suatu perusahaan dari perspektif keuangan.

d. Analisis rasio keuangan juga bermanfaat bagi para kreditor dapat digunakan untuk memperkirakan potensi risiko yang akan dihadapi dikaitkan dengan adanya jaminan kelangsungan pembayaran bunga dan pengambilan pokok pinjaman.

e. Analisis rasio keuangan dapat dijadikan sebagai penilaian bagi pihak stakeholder organisasi.

\section{Jenis Analisis Rasio Keuangan}

a. Rasio Likuiditas

Rasio likuiditas merupakan rasio yang dapat digunakan untuk mengukur sampai seberapa jauh tingkat kemampuan perusahaan dalam melunasi kewajiban jangka pendeknya yang akan segera jatuh tempo. Jika perusahaan memiliki kemampuan untuk melunasi kewajibannya maka dikatakan sebagai perusahaan yang likuid. (Hery, 2016: 150).

Jenis-jenis rasio likuiditas diantaranya adalah rasio berikut:

1) Current Ratio (Rasio Lancar)

Menurut Irham Fahmi (2012:66), rasio lancar (current ratio) adalah ukuran yang umum digunakan atas solvensi jangka pendek, kemampuan suatu perusahaan memenuhi kebutuhan utang ketika jatuh tempo. Adapun rumus current ratio adalah:

Current Ratio $=\frac{\text { Aktiva Lancar }}{\text { Hutang Lancar }} \times 100 \%$

2) Quick Ratio/Acid Test Ratio (Rasio Sangat Lancar)

Menurut Irham Fahmi (2012:70), quick ratio sering disebut dengan istilah rasio cepat. Rasio cepat adalah ukuran uji solvensi rjangka pendek yang lebih teliti dari pada rasio lancar karena pembilangnya mengeliminasi persediaan yang dianggap aktiva lancar yang sedikit tidak liquid dan kemungkinan menjadi sumber kerugian. Adapun rumus quick ratio adalah sebagai berikut:

Quick Ratio $=\frac{\text { Aktiva Lancar }- \text { Persediaan }}{\text { Hutang Lancar }} \times 100 \%$

3) Cash Ratio (Rasio Kas)

Menurut Hery (2016:142), rasio kas (cash ratio) merupakan rasio yang digunakan untuk mengukur seberapa besar uang kas atau setara kes yang tersedia untuk membayar utang jangka pendek. Ada- 
pun rumus cash ratio adalah sebagai berikut:

Cash Ratio $=\frac{\text { Kas dan Setara Kas }}{\text { Kewajiban Lancar }} \times 100 \%$

4) Cash Turnover (Rasio Perputaran Kas) Menurut Kasmir (2012:140), rasio perputaran kas (cash turn over) merupakan rasio yang berfungsi untuk mengukur tingkat kecukupan modal kerja perusahaan yang dibutuhkan untuk membayar tagihan dan membiayai penjualan. Adapun rumus cash turnover adalah sebagai berikut:

Cash Turnover $=\frac{\text { Pendapatan }}{\text { Modal Bersih Kerja }}$

\section{b. Rasio Profitabilitas}

Menurut Hery (2016:143), rasio profitabilitas merupakan rasio yang menggambarkan kemampuan perusahaan dalam menghasilkan laba. Tujuan operasional dari sebagian besar perusahaan adalah untuk memaksimalkan profit, baik profit jangka pendek maupun profit jangka panjang. Rasio profitabilitas ini juga dapat digunakan sebagai alat untuk mengukur tingkat efektivitas kinerja manajemen. Kinerja yang baik akan ditunjukkan lewat keberhasilan manajemen dalam menghasilkan laba yang maksimal bagi perusahaan.

Jenis-jenis rasio profitabilitas yang peneliti akan gunakan adalah rasio berikut:

1) Marjin Laba Kotor (Gross Profit Margin) Menurut Hery (2016:195-196), marjin laba kotor (gross profit margin) merupakan rasio yang digunakan untuk mengukur besarnya persentase laba kotor atas penjualan bersih. Rasio itu dihitung dengan membagi laba kotor dengan penjualan bersih. Semakin tinggi margin laba kotor berarti semakin tinggi pula laba kotor yang dihasilkan dari penjualan bersih. Adapun rumus gross profit margin adalah sebagai berikut:

Gross Profit Margin $=\frac{\text { Laba Kotor }}{\text { Penjualan Bersih }} \times 100 \%$
2) Marjin Laba Operasional (Operating Profit Margin)

Menurut Hery (2016:197), marjin laba operasional (operating profit margin) merupakan rasio yang digunakan untuk mengukur besarnya persentase laba operasional atas penjualan bersih. Rasio ini dihitung dengan membagi laba operasional terhadap penjualan bersih. Semakin tinggi margin laba operasional berarti semakin tinggi pula laba operasional yang dihasilkan dari penjualan bersih. Adapun rumus operating profit margin adalah sebagai berikut:

Operating Profit Margin $=\frac{\text { Laba Operasional }}{\text { Penjualan Bersih }} \times 100 \%$

3) Marjin Laba Bersih (Net Profit Marjin) Menurut Hery (2016:198-199), marjin laba bersih (net profit marjin) merupakan rasio yang digunakan untuk mengukur besarnya persentase laba bersih atas penjualan bersih. Rasio ini diukur dengan membagi laba bersih atas penjualan bersih. Adapun rumus net profit marjin adalah sebagai berikut:

Net Profit Margin $=\frac{\text { Laba Bersih }}{\text { Penjualan Bersih }} \times 100 \%$

4) Hasil Pengembangan atas Aset (Return on Assets)

Menurut Hery (2016:193), hasil pengembangan atas aset (return on assets) merupakan rasio yang menunjukkan seberapa besar aset dalam menciptakan dalam menghasilkan laba bersih. ROA digunakan untuk mengukur seberapa besar jumlah laba bersih yang akan dihasilkan dari setiap rupiah dana yang tertanam dalam total aset. ROA dihitung dengan membagi laba bersih terhadap total aset. Adapun rumus net profit marjin adalah sebagai berikut:

$$
\text { ROA }=\frac{\text { Laba Bersih }}{\text { Total Aset }} \times 100 \%
$$


5) Hasil Pengembalian atas Ekuitas (Return of Equity)

Menurut Hery (2016:194), hasil pengembalian atas ekuitas (return of equity) merupakan rasio yang menunjukkan seberapa besar kontribusi ekuitas dalam menciptakan laba bersih. ROE digunakan untuk mengukur seberapa besar jumlah laba bersih yang akan dihasilkan dari setiap rupiah dana yang tertanam dalam total ekuitas. ROE dihitung dengan membagi laba bersih terhadap total ekuitas. Adapun rumus return of equity adalah sebagai berikut:

$$
\text { ROE }=\frac{\text { Laba Bersih }}{\text { Total Ekuitas }} \times 100 \%
$$

\section{c. Rasio Aktivitas}

Rasio aktivitas merupakan rasio yang digunakan untuk mengukur efektivitas perusahaan dalam menggunakan aset yang dimilikinya, termasuk untuk mengukur tingkat efisiensi perusahaan dalam memanfaatkan sumber daya yang ada. Rasio ini juga digunakan untuk menilai kemampuan perusahaan dalam melaksanakan aktivitas seharihari. (Hery, 2016:178)

Jenis-jenis rasio aktivitas yang peneliti akan gunakan adalah rasio berikut:

1) Perputaran Piutang Usaha (Accounts Receivable Turn Over)

Menurut Hery (2016:179), perputaran piutang usaha (accounts receivable turn over) merupakan rasio yang digunakan untuk mengukur berapa kali dana yang tertanam berputar dalam satu periode atau berapa lama penagihan piutang usaha. Rasio ini menunjukkan kualitas piutang usaha dan kemampuan manajemen dalam melakukan aktivitas penagihan piutang usaha tersebut. Adapun rumus perputaran piutang usaha adalah sebagai berikut:

Perputaran Piutang Usaha $=\frac{\text { Penjualan Kredit }}{\text { Rata-rata Piutang Usaha }}$
2) Perputaran Aset Tetap (Fixed Assets Turn Over)

Menurut Hery (2016:185-186) perputaran aset tetap (fixed assets turn over) merupakan rasio yang digunakan untuk mengukur keefektifan aset tetap yang dimilikiperusahaandalammenghasilkan penjualan atau dengan kata lain untuk mengukur seberapa efektif kapasitas aset tetap turut berkontribusi menciptakan penjualan. Rasio ini dihitung sebagai hasil bagi antara penjualan dengan aset tetap. Perputaran aset tetap yang rendah berarti perusahaan memiliki kelebihan kapasitas aset tetap, dimana aset tetap yang ada belum dimanfaatkan secara maksimal untuk menciptakan penjualan. Adapun rumus fixed assets turnover adalah sebagai berikut:

Fixed Assets Turnover $=\frac{\text { Penjualan }}{\text { Aktiva Tetap }} \times 100 \%$

3) Perputaran Total Aset (Total Assets Turn Over)

Menurut Hery (2016:187) perputaran total aset (total assets turn over) merupakan rasio yang digunakan untuk mengukur keefektifan total aset yang dimiliki perusahaan dalam menghasilkan penjualan dari setiap rupiah dana yang tertanam dalam total aset. Rasio dihitung sebagai hasil bagi antara besarnya penjualan dengan total aset. Perputaran total aset yang ada belum dimanfaatkan secara maksimal untuk menciptakan penjualan. Adapun rumus total assets turnover adalah sebagai berikut:

Total Assets Turnover $=\frac{\text { Penjualan }}{\text { Total Aktiva }} \times 100 \%$

4) Perputaran Modal Kerja (Working Turn Over)

Menurut Hery (2016:184), perputaran modal kerja (working turn over) merupakan rasio yang digunakan untuk mengukur keefektifan modal kerja (aset 
lancar) yang dimiliki perusahaan dalam menghasilkan penjualan. Rasio ini dihitung sebagai hasil bagi antara besarnya penjualan dengan modal aset lancar. Perputaran modal kerja yang rendah berarti perusahaan sedang memiliki kelebihan modal kerja. Hal ini mungkin disebabkan karena rendahnya perputaran persediaan barang dagang bisa juga karena terlalu besarnya Saldo kas. Adapun rumus working turnover adalah sebagai berikut:

Working Capital Turnover $=\frac{\text { Penjualan }}{\text { Aktiva Lancar }} \times 100 \%$

\section{d. Rasio Solvabilitas}

Menurut Hery (2016:162) rasio solvabilitas atau rasio leverage merupakan rasio yang digunakan untuk mengukur sejauh mana aset perusahaan dibiayai dengan hutang. Dalam arti luas, rasio solvabilitas digunakan untuk mengukur kemampuan perusahaan dalam memenuhi seluruh kewajibannya, baik kewajiban jangka pendek maupun kewajiban jangka panjang.

Jenis-jenis rasio solvabilitas diantaranya sebagai berikut:

1) Rasio Utang terhadap Aset (Debt to Asset Ratio)

Menurut Hery (2016:166), rasio utang terhadap aset (debt to asset ratio) merupakan rasio yang digunakan untuk mengukur perbandingan antara total utang dengan total aset. Rasio utang terhadap aset digunakan untuk mengukur seberapa besar aset perusahaan dibiayai oleh utang atau seberapa besar utang perusahaan berpengaruh terhadap pembiayaan aset. Adapun rumus debt to asset ratio adalah sebagai berikut:

Debt to Asset Ratio $=\frac{\text { Total Utang }}{\text { Total Aset }} \times 100 \%$

2) Rasio Utang terhadap Modal (Debt to Equity Ratio)

Rasio utang terhadap modal (debt to equity ratio) merupakan rasio yang di- gunakan untuk mengukur besarnya proporsi uatng terhadap modal. Rasio utang terhadap modal dihitung sebagai hasil bagi antara total hutang dengan modal. Rasio utang terhadap modal berguna untuk mengetahui berapa bagian dari setiap rupiah modal yang dijadikan sebagai jaminan utang. (Hery, 2016:168169) Adapun rumus debt to equity ratio adalah sebagai berikut:

Debt to Equity Ratio $=\frac{\text { Total Utang }}{\text { Total Ekuitas }} \times 100 \%$

3) Rasio Utang Jangka Panjang terhadap Modal (Long Term Debt to Equity Ratio) Menurut Hery (2016:170), rasio utang jangka panjang terhadap modal (long term debt to equity ratio) merupakan rasio yang digunakan untuk mengukur besarnya proporsi utang jangka panjang terhadap modal. Rasio ini berguna untuk mengetahui berapa bagian dari setiap rupiah modal yang dijadikan sebagai jaminan utang jangka panjang. Rasio ini dihitung sebagai hasil bagi antara utang jangka panjang dengan modal. Adapun rumus long term debt to equity ratio adalah sebagai berikut:

Long Term Debt

to Equity Ratio $=\frac{\text { Total Utang Jangka Panjang }}{\text { Total Ekuitas }} \times 100 \%$

\section{e. Rasio Arus Kas}

Menurut Hery (2016:106), data laporan arus kas dapat digunakan untuk menghitung rasio tertentu yang menggambarkan kekuatan keuangan perusahaan. Analisis laporan arus kas ini menggunakan komponen laporan arus kas dan juga komponen neraca serta laporan laba-rugi sebagai alat analisis rasio.

Jenis-jenis rasio arus kas adalah sebagai berikut:

1) Rasio Arus Kas Operasi terhadap Kewajiban Lancar

Menurut Hery (2016-106), rasio arus kas operasi terhadap kewajiban lancar menunjukkan kemampuan arus kas 
operasi perusahaan dalam melunasi kewajiban lancarnya. Rasio ini dihitung sebagai hasil bagi antara arus kas operasi dengan total kewajiban lancar. Adapun rumus rasio arus kas operasi terhadap kewajiban lancar adalah sebagai berikut:

Rasio Arus Kas Operasi $=\frac{\text { Arus Kas Koperasi }}{\text { Utang Lancar }} \times 100 \%$

2) Rasio Arus Kas Operasi terhadap Pengeluaran Modal

Rasio ini digunakan untuk mengukur arus kas operasi yang tersedia untuk pengeluaran investasi. Rasio arus kas operasi terhadap pengeluaran modal dihitung sebagai hasil bagi antara arus kas operasi dengan kas yang dibayarkan untuk pengeluaran modal, seperti pembelian aset tetap, akuisisi bisnis, dan aktivitas investasi lainnya. (Hery, 2016:107) Adapun rumus rasio arus kas operasi terhadap pengeluaran modal adalah sebagai berikut:

Rasio Pengeluaran Modal $=\frac{\text { Arus Kas Koperasi }}{\text { Pengeluaran Modal }}$

3) Rasio Arus Kas Operasi terhadap Total Hutang

Rasio arus kas operasi terhadap total utang menunjukkan kemampuan arus kas operasi perusahaan dalam melunasi seluruh kewajibannya, baik kewajiban lancar maupun kewajiban jangka panjang. Rasio arus kas operasi terhadap total hutang dihitung sebagai hasil bagi antara arus kas operasi dengan total hutang. (Hery, 2016:107) Adapun rumus rasio arus kas operasi terhadap total hutang adalah sebagai berikut:

Rasio Total Hutang $=\frac{\text { Arus Kas Koperasi }}{\text { Total Utang }} \times 100 \%$

4. Standar Rasio Keuangan

Metode analisis data dalam penelitian ini adalah metode deskriptif yaitu suatu metode penelitian yang bertujuan menggambarkan keadaan objek yang diteliti berdasarkan fakta-fakta yang ada dengan cara mengumpulkan, mengolah, menyajikan serta menganalisis berbagai data yang ditemukan dan membandingkannya dengan teori yang ada, kemudian dianalisis penerapannya dalam praktek sehingga dapat ditarik kesimpulan.

Dalam penyusunan penelitian ini penulis memperoleh data-data yang diperlukan berkaitan dengan objek penelitiannya yaitu neraca, laporan laba rugi, dan laporan perubahan modal. Metode analisis data yang digunakan penulis adalah metode analisis Rasio Aktivitas dan Rasio Rentabilitas.

Untuk mengukur kinerja keuangan atau kesehatan perusahaan, Berikut adalah tabel standar industri rata-rata:

\begin{tabular}{|c|c|c|c|c|c|}
\hline \multicolumn{6}{|c|}{$\begin{array}{c}\text { Tabel 2. Standar Industri Rasio } \\
\text { Likuiditas, Profitabilitas, Aktivitas, dan Solvabilitas }\end{array}$} \\
\hline \multirow{2}{*}{ No } & \multirow{2}{*}{ Jenis Rasio } & \multirow{2}{*}{ Alat Ukur } & \multicolumn{3}{|c|}{ Kondisi Perusahaan } \\
\hline & & & Sangat Baik & Baik & Kurang Baik \\
\hline \multirow{4}{*}{1} & \multirow{4}{*}{ Likuiditas } & Current Ratio & $>200 \%$ & $200 \%$ & $<200 \%$ \\
\hline & & Quick Ratio & $>150 \%$ & $150 \%$ & $<150 \%$ \\
\hline & & Cash Ratio & $>50 \%$ & $50 \%$ & $<50 \%$ \\
\hline & & Cash Turnover & $>10 \%$ & $10 \%$ & $<10 \%$ \\
\hline \multirow{3}{*}{2} & \multirow{3}{*}{ Profitabilias } & Net Profit Margin & $>20 \%$ & $20 \%$ & $<20 \%$ \\
\hline & & Return On Assets & $>30 \%$ & $30 \%$ & $<30 \%$ \\
\hline & & Return On Equity & $>40 \%$ & $40 \%$ & $<40 \%$ \\
\hline \multirow{4}{*}{3} & \multirow{4}{*}{ Aktivitas } & $\begin{array}{l}\text { Receivable } \\
\text { Turnover }\end{array}$ & > 15 Kali & 15 Kali & $<15$ Kali \\
\hline & & $\begin{array}{l}\text { Working Capital } \\
\text { Turnover }\end{array}$ & $>6$ Kali & 6 Kali & $<6$ Kali \\
\hline & & $\begin{array}{l}\text { Fixed Assets } \\
\text { Turnover }\end{array}$ & $>5$ Kali & 5 Kali & $<5$ Kali \\
\hline & & $\begin{array}{l}\text { Total Assets } \\
\text { Turnover }\end{array}$ & $>2$ Kali & 2 Kali & $<2$ Kali \\
\hline \multirow{3}{*}{4} & \multirow{3}{*}{ Solvabilitas } & $\begin{array}{l}\text { Debt to Asset } \\
\text { Ratio }\end{array}$ & $>35 \%$ & $35 \%$ & $<35 \%$ \\
\hline & & $\begin{array}{l}\text { Debt to Equity } \\
\text { Ratio }\end{array}$ & $>90 \%$ & $90 \%$ & $<90 \%$ \\
\hline & & $\begin{array}{l}\text { Long Term Debt } \\
\text { to Equity Ratio }\end{array}$ & > 10 Kali & 10 Kali & $<10$ Kali \\
\hline & & & & ber: Kasm & 2012 : 143-208 \\
\hline
\end{tabular}

\section{Kinerja Keuangan}

\section{Definisi Kinerja Keuangan}

Pengukuran kinerja keuangan merupakan suatu usaha formal untuk mengevaluasi efiensi dan efektivitas perusahaan dalam menghasilkan laba dan posisi kas tertentu. Dengan pengukuran kinerja keuangan ini 
dapat dilihat prospek pertumbuhan dan perkembangan keuangan perusahaan dari mengandalkan sumber yang dimilikinya. Perusahaan dikatakan berhasil apabila mencapai suatu kinerja yang telah ditetapkan. (Hery, 2016:25)

Kinerja keuangan adalah suatu analisis yang dilakukan untuk melihat sejauh mana suatu perusahaan telah melaksanakan dengan menggunakan aturan-aturan pelaksanaan keuangan secara baik dan benar. Seperti dengan membuat suatu laporan keuangan yang telah memenuhi standar dan ketentuan dalam SAK (Standar Akuntansi Keuangan) atau GAAP (General Accepted Accounting Principle) dan yang lainnya. (Irham Fahmi, 2012:2)

Dari beberapa pengertian di atas, dapat disimpulkan bahwa kinerja keuangan adalah hasil dari pencapaian perusahaan berdasarkan pengukuran kinerja keuangan dan ketentuan standar akuntansi keuangan dapat dilihat dari prospek pertumbuhan dan perkembangan keuangan perusahaan mengandalkan sumber yang dimilikinya yang telah sehingga tercapainya suatu prestasi dalam satu periode tertentu yang mencerminkan tingkat kesehatan perusahaan.

\section{Tahap-Tahap Menganalisis Kinerja Keuangan}

Menurut Irham Fahmi (2014:3-4), ada 5 (lima) tahap dalam menganalisiskinerja keuangan suatu perusahaan secara umum yaitu:

a. Melakukan review terhadap data laporan keuangan.

Review di sini dilakukan dengan tujuan agar laporan keuangan yang sudah dibuat tersebut sesuai dengan penerapan kaidah-kaidah yang berlaku umum dalam dunia akuntansi, sehingga dengan demikian hasil laporan keuangan tersebut dapat dipertanggungjawabkan.

b. Melakukan perhitungan.

Penerapan metode perhitungan di sini adalah disesuaikan dengan kondisi dan permasalahan yang sedang dilakukan sehingga hasil dari perhitungan tersebut akan memberikan suatu kesimpulan sesuai dengan analisis yang diinginkan.

c. Melakukan perbandingan terhadap hasil hitungan yang telah diperoleh.

Dari hasil hitungan yang sudah diperoleh tersebut kemudian dilakukan perbandingan dengan hasil hitungan dari berbahai perusahaan lainnya. Terdapat dua metode yang paling umum dipergunakan untuk melakukan perbandingan ini yaitu:

1) Times series analysis, yaitu membandingkan secara antar-waktu atau peride, dengan tujuan itu nantinya akan terlihat secara grafik.

2) Cross sectional approach, yaitu melakukan perbandingan terhadap hasil hitungan rasio-rasio yang telah dilakukan antara satu perusahaan dan perusahaan lainnya dalam ruang lingkup yang sejenis yang dilakukan bersamaan.

Dari hasil metode diatas diharapkan nantinya dapat disimpulkan yang menyatakan posisi perusahaan tersebut berada dalam kondisi sangat baik, baik, sedang/normal, tidak baik, dan sangat tidak baik.

d. Melakukan penafsiran (interpretation) terhadap berbagai permasalahan yang ditemukan.

Pada tahap ini analisis melihat kinerja keuangan perusahaan adalah setelah dilakukan ketiga tahap tersebut selanjutnya dilakukan penafsiran untuk melihat apa-apa saja permasalahan dan kendalakendala yang dialami oleh perusahaan tersebut.

e. Mencari dan memberikan pemecahan masalah (solution) terhadap berbagai permasalahan yang ditemukan.

Pada tahap terakhir ini setelah ditemukan berbagai permasalahan yang dihadapi maka dicarikan solusi guna memberikan suatu input atau masukan agar apa yang menjadi kendala dan hambatan selama 
ini dapat terselesaikan.

3. Penilaian Kinerja Keuangan Perusahaan dengan Menggunakan Analisis Rasio Keuangan

Menurut Hery (2017:25), penilaian atau pengukuran kinerja keuangan merupakan suatu formal untuk mengevaluasi efisiensi dan efektivitas perusahaan dalam menghasilkan laba dan posisi kas tertentu. Dengan pengukuran kinerja keuangan ini dapat prospek pertumbuhan dan perkembangan keuangan perusahaan dari mengandalkan sumber daya yang dimilikinya. Perusahaan dikatakan berhasil apabila perusahaan telah mencapai suatu kinerja tertentu yang telah ditetapkan.

Pengukuran kinerja keuangan adalah penting sebagai sarana atau indikator dalam rangka memperbaiki kegiatan operasional perusahaan. Dengan perbaikan kinerja operasional diharapkan bahwa perusahaan dapat mengalami pertumbuhan keuangan yang lebih baik dan juga dapat bersaing dengan perusahaan lain lewat efisiensi dan efektivitas.

Pengukuran kinerja keuangan dilakukan bersamaan dengan proses analisis. Analisis kinerja keuangan merupakan suatu proses pengkajian kinerja keuangan secara kritis, yang meliputi peninjauan data keuangan, penghitungan, pengukuran, interpretasi, dan pemberian solusi terhadap masalah keuangan perusahaan pada suatu periode tertentu. Seperti yang telah disebutkan pada pembahasan sebelumnya, bahwa kinerja keuangan perusahaan dapat dinilai dengan menggunakan beberapa alat analisis. Di mana salah satunya dengan menggunakan alat analisis rasio keuangan.

\section{METODE}

\section{Lokasi Penelitian}

lokasi penelitian ini adalah perusahaan yang terdaftar di Bursa Efek Indonesia (BEI) yang berlokasi di Gedung Bursa Efek Jakarta, Tower II, Lantai 1, Jalan Jenderal Sudirman Kav. 52-53, Senayan, Kebayoran Baru, Jakarta Selatan 12190 yang dapat di akses melalui $w w w . i d x$.co.id.
Yaitu PT. Telekomunikasi Indonesia (Persero) Tbk yang merupakan salah satu Perusahaan BUMN yang bergerak di bidang Jaringan dan Jasa Telekomunikasi yang berkantor pusat di alamat Jalan Jendral Gatot Subroto Kav. 52 RT 006/RW 011, Kuningan Barat, Mampang Prapatan Jakarta Selatan, DKI Jakarta, 12710.

\section{Waktu Penelitian}

Untuk memperoleh data dan informasi yang diperlukan dalam penyusunan skripsi ini melakukan penelitian selama 4 bulan yaitu Mei 2018 sampai dengan bulan Agustus 2018.

\section{Sifat Penelitian}

Penelitian yang digunakan oleh penulis bersifat deskriptif kuantitatif, maksudnya penelitian yang menggambarkan atau menceritakan serta menguraikan bagaimana hasil dari perhitungan data-data finansial perusahaan dalam bentuk laporan keuangan.

Data yang diambil dalam penelitian dan penulisan skripsi ini adalah data-data yang terdapat dalam laporan keuangan PT. Telekomunikasi Indonesia (Persero) Tbk selama sebelas periode dari 2007-2015.

\section{Populasi}

Populasi yang digunakan dalam penelitian ini adalah laporan keuangan PT. Telekomunikasi Indonesia (Persero) Tbk yang dipublikasikan Bursa Efek Indonesia (BEI).

\section{Sampel}

Sampel penelitian ini adalah laporan neraca dan laporan laba rugi pada PT. Telekomunikasi Indonesia (Persero) Tbk yang dipublikasikan Bursa Efek Indonesia (BEI) dari tahun 2007 sampai dengan 2015.

\section{Metode Pengumpulan Data}

Metode yang digunakan dalam pengumpulan data untuk melakukan penelitian ini adalah sebagai berikut:

1. Penelitian Kepustakaan (Library Research)

Data yang diperoleh untuk penelitian ini adalah data yang diperoleh dengan membaca literatur, buku, artikel, jurnal dan hal lain 
yang berhubungan dengan aspek yang diteliti sebagai upaya untuk memperoleh data yang valid.

2. Penelitian Internet (Internet Research)

Tak dapat dipungkiri terkadang buku referensi atau literatur yang kita miliki atau meminjam dari perusahaan di perpustakaan tertinggal selama beberapa waktu atau kadaluarsa, karena ilmu selalu berkembang, maka penulis melakukan penelitian dengan teknologi yang berkembang yaitu internet.

3. Dokumentasi

Menurut Uhar Suharsaputra (2014:215), dokumen merupakan rekaman kejadian masa lalu yang tertulis atau dicetak mereka dapat berupa catatan anekdot, surat, buku harian, dan dokumen-dokumen.

\section{Metode Analisis Data}

Metode analisis data dalam penelitian ini adalah metode deskriptif analisis, yaitu suatu metode penelitian yang bertujuan menggambarkan keadaan objek yang diteliti berdasarkan fakta-fakta yang ada dengan cara mengumpulkan, mengolah, menyajikan serta menganalisis berbagai data yang ditemukan dan membandingkannya dengan teori yang ada, kemudian dianalisis penerapannya dalam praktek sehingga dapat ditarik kesimpulan.

Dalam penyusunan skripsi ini penulis memperoleh data-data yang diperlukan berkaitan dengan objek penelitian terdiri dari laporan keuangan yaitu neraca, laporan laba rugi, dan laporan perubahan modal.

Metode analisis data yang digunakan penulis adalah metode analisis rasio rentabilitas dan rasio aktivitas. Metode ini dilakukan untuk mencapai suatu kesimpulan data-data yang terkumpul dengan teori-teori yang seharusnya, kemudian dilanjutkan dengan melakukan analisis. Metode analisis data yang digunakan penulis adalah metode analisis Rasio. Metode ini digunakan untuk mencapai kesimpulan daya yang terkumpul dengan teori-teori yang seharusnya, kemudian dilanjutkan dengan melakukan analisis.

\section{Rasio Rentabilitas}

Menurut Hery (2016:143), rasio rentabilitas (profitabilitas) merupakan rasio yang menggambarkan kemampuan perusahaan dalam menghasilkan laba. Tujuan operasional dari sebagian besar perusahaan adalah untuk memaksimalkan profit, baik profit jangka pendek maupun profit jangka panjang. Rasio rentabilitas ini juga dapat digunakan sebagai alat untuk mengukur tingkat efektivitas kinerja manajemen. Kinerja yang baik akan ditunjukkan lewat keberhasilan manajemen dalam menghasilkan laba yang maksimal bagi perusahaan.

1) Hasil Pengembalian Atas Investasi (Return on Investment) / ROI

Menurut Hery (2016:193), hasil pengembangan atas aset (return on investment) merupakan rasio yang menunjukkan seberapa besar aset dalam menciptakan dalam menghasilkan laba bersih. ROI digunakan untuk mengukur seberapa besar jumlah laba bersih yang akan dihasilkan dari setiap rupiah dana yang tertanam dalam total aset. ROI dihitung dengan membagi laba bersih terhadap total aset. Adapun rumus return on assets adalah sebagai berikut:

Returm On Investment $=\frac{\text { Laba Bersih }}{\text { Total Aset }} \times 100 \%$

2) Hasil Pengembalian Atas Ekuitas (Return on Equity)

MenurutHery(2016:194), hasil pengembalian atas ekuitas (return on equity) merupakan rasio yang menunjukkan seberapa besar kontribusi ekuitas dalam menciptakan laba bersih. ROE digunakan untuk mengukur seberapa besar jumlah laba bersih yang akan dihasilkan dari setiap rupiah dana yang tertanam dalam total ekuitas. ROE dihitung dengan membagi laba bersih terhadap total ekuitas. Adapun rumus return on equity adalah sebagai berikut:

$$
\text { Return On Equity }=\frac{\text { Laba Bersih }}{\text { Total Ekuitas }} \times 100 \%
$$

\section{Rasio Aktivitas}

Rasio aktivitas merupakan rasio yang digunakan untuk mengukur efektivitas perusahaan dalam menggunakan aset yang dimilikinya, ter- 
masuk untuk mengukur tingkat efisiensi perusahaan dalam memanfaatkan sumber daya yang ada. Rasio ini juga digunakan untuk menilai kemampuan perusahaan dalam melaksanakan aktivitas sehari-hari. (Hery, 2016:178).

1) Perputaran Aset Tetap (Fixed Assets Turn Over)

Menurut Hery (2016:185-186), perputaran aset tetap (fixed assets turn over) merupakan rasio yang digunakan untuk mengukur keefektifanasettetapyangdimilikiperusahaan dalam menghasilkan penjualan atau dengan kata lain untuk mengukur seberapa efektif kapasitas aset tetap turut berkontribusi menciptakan penjualan. Rasio ini dihitung sebagai hasil bagi antara penjualan dengan aset tetap. Perputaran aset tetap yang rendah berarti perusahaan memiliki kelebihan kapasitas aset tetap, dimana aset tetap yang ada belum dimanfaatkan secara maksimal untuk menciptakan penjualan. Adapun rumus fixed assets turnover adalah sebagai berikut:

Fixed Assets Turnover $=\frac{\text { Penjualan }}{\text { Aktiva Tetap }} \times 100 \%$

2) Perputaran Total Aset (Total Assets Turn Over)

Menurut Hery (2016:187), perputaran total aset (total assets turn over) merupakan rasio yang digunakan untuk mengukur keefektifan total aset yang dimiliki perusahaan dalam menghasilkan penjualan dari setiap rupiah dana yang tertanam dalam total aset. Rasio dihitung sebagai hasil bagi antara besarnya penjualan dengan total aset. Perputaran total aset yang ada belum dimanfaatkan secara maksimal untuk menciptakan penjualan. Adapun rumus total assets turnover adalah sebagai berikut:

Total Assets Turnover $=\frac{\text { Penjualan }}{\text { Total Aktiva }} \times 100 \%$

\section{Standar Rasio Keuangan}

Untuk mengukur kinerja keuangan atau kesehatan perusahaan, berikut adalah tabel ratarata standar industri yang dijadikan penulis dalam menganalisa laporan keuangan PT. Teleko- munikasi Indonesia (Persero) Tbk :

\begin{tabular}{c|c|c|c|c|c|}
\hline \multicolumn{5}{c|}{ Tabel 3. Standar Industri Rasio Aktivitas dan Rentabilitas } \\
\cline { 4 - 6 } No & \multirow{2}{*}{ Jenis Rasio } & Alat Ukur & \multicolumn{3}{|c}{ Kondisi Perusahaan } \\
\cline { 4 - 6 } & \multirow{2}{*}{ Aktivitas } & $\begin{array}{l}\text { Fixed Asset } \\
\text { Turnover }\end{array}$ & $>5$ Kali & 5 Kali & $<5$ Kali \\
\cline { 4 - 6 } & & $\begin{array}{l}\text { Total Assets } \\
\text { Turnover }\end{array}$ & $>2$ Kali & 2 Kali & $<2$ Kali \\
\hline 3 & \multirow{2}{*}{ Rentabilitas } & $\begin{array}{l}\text { Return On } \\
\text { Investment }\end{array}$ & $>30 \%$ & $30 \%$ & $<30 \%$ \\
\cline { 4 - 6 } & Return On Equity & $>40 \%$ & $40 \%$ & $<40 \%$ \\
\hline
\end{tabular}

\section{Operasional Variabel}

1. Rasio Keuangan

Menurut (Kasmir, 2012:93), rasio keuangan merupakan kegiatan membandingkan angka-angka yang ada dalam laporan keuangan dengan cara membagi satu angka dengan angka lainnya. Perbandingan dapat dilakukan antara satu komponen dengan komponen dalam satu laporan keuangan atau antar komponen yang ada diantara laporan keuangan. Kemudian angka yang diperbandingkan dapat berubah angka-angka dalam satu periode maupun beberapa periode.

2. Kinerja Keuangan

Kinerja perusahaan merupakan suatu gambaran tentang kondisi keuangan suatu perusahaan yang dianalisis dengan alat-alat analisis keuangan, sehingga dapat diketahui mengenai baik buruknya keadaan keuangan suatu perusahaan yang mencerminkan prestasi kerja dalam periode tertentu. Hal ini sangat penting agar sumber daya digunakan secara optimal dalam menghadapi perubahan lingkungan.

Untuk mengukur kinerja keuangan atau kesehatan PT. Telekomunikasi Indonesia (Persero) Tbk, maka penulis membandingkan hasil rasio aktivitas dan rasio rentabilitas dengan standar rasio yang sesuai dengan buku Kasmir yang berjudul Analisis Laporan Keuangan 2012. 


\begin{tabular}{l|l|l|c|}
\multicolumn{1}{c}{ Tabel 4. Standar Industri Rasio Aktivitas dan Rentabilitas } \\
\hline \multicolumn{1}{c|}{ Variabel } & \multicolumn{1}{c|}{ Definisi Variabel } & \multicolumn{1}{c}{ Indikator } & Skala \\
$\begin{array}{l}\text { Rasio } \\
\text { Aktivitas }\end{array}$ & $\begin{array}{l}\text { Rasio Aktivitas adalah efektifitas } \\
\text { perusahaan dalam penggunaan } \\
\text { sumber daya yang dimiliki. }\end{array}$ & $\begin{array}{l}\text { a. Fixed Assets } \\
\text { Turnover } \\
\text { b. Total Assets } \\
\text { Turnover }\end{array}$ & Rasio \\
\hline $\begin{array}{l}\text { Rasio } \\
\text { Rentabilitas }\end{array}$ & $\begin{array}{l}\text { Rasio Rentabilitas adalah } \\
\text { kemampuan perusahaan untuk } \\
\text { memperoleh laba. }\end{array}$ & $\begin{array}{l}\text { a. ROI } \\
\text { b. ROE }\end{array}$ & Rasio \\
\hline $\begin{array}{l}\text { Kinerja } \\
\text { Keuangan }\end{array}$ & $\begin{array}{l}\text { Kinerja Keuangan adalah suatu } \\
\text { gambaran tentang kondisi } \\
\text { keuangan perusahaan pada } \\
\text { periode tertentu dengan mengacu } \\
\text { pada standar yang ditetapkan }\end{array}$ & $\begin{array}{l}\text { Analisis laporan } \\
\text { keuangan } \\
\text { menggunakan } \\
\text { rasio keuangan }\end{array}$ & Rasio \\
\hline
\end{tabular}

\section{HASIL dan PEMBAHASAN}

\section{A. Rasio Aktivitas PT. Telekomunikasi Indo- nesia (Persero) Tbk}

Rasio aktivitas merupakan rasio yang digunakan untuk mengukur efektivitas perusahaan dalam menggunakan aset yang dimilikinya, termasuk untuk mengukur tingkat efisiensi perusahaan dalam memanfaatkan sumber daya yang ada. Dalam penelitian ini rasio aktivitas yang digunakan meliputi fixed assets turnover dan total assets turn over.

a. Perputaran Aktiva Tetap (Fixed Assets Turn over)

Dalam mencari nilai fixed assets turnover atau perputaran aktiva tetap data yang digunakan adalah penjualan dan total aktiva tetap.

Rumus yang digunakan untuk mendapatkan nilai fixed assets turnover adalah :

$$
\text { Fixed Assets Turnover }=\frac{\text { Penjualan }}{\text { Total Aktiva Tetap }} \times 100 \%
$$

\begin{tabular}{|c|c|c|c|c|c|}
\hline \multicolumn{6}{|c|}{$\begin{array}{l}\text { Tabel 5. Komponen Fixed Assets Turnover } \\
\text { PT. Telekomunikasi Indonesia (Persero) Tbk Tahun } 2007 \text { - } 2015\end{array}$} \\
\hline Tahun & Penjualan & $\begin{array}{l}\text { Total Aktiva } \\
\text { Tetap }\end{array}$ & $\begin{array}{c}\text { Fixed } \\
\text { Assets } \\
\text { Turnover }\end{array}$ & $\begin{array}{l}\text { Standar } \\
\text { Industri }\end{array}$ & Hasil \\
\hline 2007 & 59.440 & 66.478 & 0,89 Kali & \multirow{9}{*}{5 Kali } & Kurang Baik \\
\hline 2008 & 60.690 & 76.732 & 0,79 Kali & & Kurang Baik \\
\hline 2009 & 64.597 & 81.870 & 0,79 Kali & & Kurang Baik \\
\hline 2010 & 69.177 & 81.772 & 0,85 Kali & & Kurang Baik \\
\hline 2011 & 71.918 & 81.796 & 0,88 Kali & & Kurang Baik \\
\hline 2012 & 77.143 & 83.396 & 0,93 Kali & & Kurang Baik \\
\hline 2013 & 82.967 & 94.876 & 0,87 Kali & & Kurang Baik \\
\hline 2014 & 89.696 & 107.133 & 0,84 Kali & & Kurang Baik \\
\hline 2015 & 102.470 & 118.261 & 0,87 Kali & & Kurang Baik \\
\hline
\end{tabular}

Pada tahun 2007 fixed assets turnover atau perputaran aktiva tetap PT. Telekomunikasi Indonesia (Persero) Tbk adalah 0,89 kali. Artinya setiap Rp1 aktiva tetap dapat menghasilkan Rp0,89 penjualan. Pada tahun 2008 fixed assets turnover atau perputaran aktiva tetap PT. Telekomunikasi Indonesia (Persero) Tbk adalah 0,79 kali. Artinya setiap Rp1 aktiva tetap dapat menghasilkan Rp0,79 penjualan. Pada tahun 2009 fixed assets turnover atau perputaran aktiva tetap PT. Telekomunikasi Indonesia (Persero) Tbk adalah 0,79 kali. Artinya setiap Rp1 aktiva tetap dapat menghasilkan Rp0,79 penjualan. Pada tahun 2010 fixed assets turnover atau perputaran aktiva tetap PT. Telekomunikasi Indonesia (Persero) Tbk adalah 0,85 kali. Artinya setiap Rp1 aktiva tetap dapat menghasilkan Rp0,85 penjualan. Pada tahun 2011 fixed assets turnover atau perputaran aktiva tetap PT. Telekomunikasi Indonesia (Persero) Tbk adalah 0,88 kali. Artinya setiap Rp1 aktiva tetap dapat menghasilkan Rp0,88 penjualan. Pada tahun 2012 fixed assets turnover atau perputaran aktiva tetap PT. Telekomunikasi Indonesia (Persero) Tbk adalah 0,93 kali. Artinya setiap Rp1 aktiva tetap dapat menghasilkan Rp0,93 penjualan. Pada tahun 2013 fixed assets turnover atau perputaran aktiva tetap PT. Telekomunikasi Indonesia (Persero) Tbk adalah 0,87 kali. Artinya setiap Rp1 aktiva tetap dapat menghasilkan Rp0,87 penjualan. Pada tahun 2014 fixed assets turnover atau perputaran aktiva tetap PT. Telekomunikasi Indonesia (Persero) Tbk adalah 0,84 kali. Artinya setiap Rp1 aktiva tetap dapat menghasilkan Rp0,84 penjualan. Pada tahun 2015 fixed assets turnover atau perputaran aktiva tetap PT. Telekomunikasi Indonesia (Persero) Tbk adalah 0,87 kali. Artinya setiap Rp1 aktiva tetap dapat menghasilkan Rp0,87 penjualan.

b. Perputaran Total Aktiva (Total Assets Turn over)

Dalam mencari nilai total assets turnover data yang digunakan adalah penjualan dan total aktiva. Rumus yang digunakan untuk 
mendapatkan nilai total assets turnover adalah:

Total Assets Turnover $=\frac{\text { Penjualan }}{\text { Total Aktiva }} \times 100 \%$

\begin{tabular}{|c|c|c|c|c|c|}
\hline \multicolumn{6}{|c|}{$\begin{array}{l}\text { Tabel 6. Komponen Total Assets Turnover } \\
\text { PT. Telekomunikasi Indonesia (Persero) Tbk Tahun } 2007 \text { - } 2015\end{array}$} \\
\hline Tahun & Penjualan & Total Aktiva & $\begin{array}{l}\text { Total Assets } \\
\text { Turnover }\end{array}$ & $\begin{array}{l}\text { Standar } \\
\text { Industri }\end{array}$ & Hasil \\
\hline 2007 & 59.440 & 82.457 & 0,72 Kali & \multirow{9}{*}{2 Kali } & Kurang Baik \\
\hline 2008 & 60.690 & 91.355 & 0,66 Kali & & Kurang Baik \\
\hline 2009 & 64.597 & 98.056 & 0,66 Kali & & Kurang Baik \\
\hline 2010 & 69.177 & 100.501 & 0,69 Kali & & Kurang Baik \\
\hline 2011 & 71.918 & 103.054 & 0,70 Kali & & Kurang Baik \\
\hline 2012 & 77.143 & 111.369 & 0,69 Kali & & Kurang Baik \\
\hline 2013 & 82.967 & 127.951 & 0,65 Kali & & Kurang Baik \\
\hline 2014 & 89.696 & 140.895 & 0,64 Kali & & Kurang Baik \\
\hline 2015 & 102.47 & 166.173 & 0,62 Kali & & Kurang Baik \\
\hline
\end{tabular}

Pada tahun 2007 total assets turnover atau perputaran aktiva tetap PT. Telekomunikasi Indonesia (Persero) Tbk adalah 0,72 kali. Artinya setiap Rp1 aktiva tetap dapat menghasilkan Rp0,72 penjualan. Pada tahun 2008 total assets turnover atau perputaran aktiva tetap PT. Telekomunikasi Indonesia (Persero) Tbk adalah 0,66 kali. Artinya setiap Rp1 aktiva tetap dapat menghasilkan Rp0,66 penjualan. Pada tahun 2009 total assets turnover atau perputaran aktiva tetap PT. Telekomunikasi Indonesia (Persero) Tbk adalah 0,66 kali. Artinya setiap Rp1 aktiva tetap dapat menghasilkan Rp0,66 penjualan. Pada tahun 2010 total assets turnover atau perputaran aktiva tetap PT. Telekomunikasi Indonesia (Persero) Tbk adalah 0,69 kali. Artinya setiap Rp1 aktiva tetap dapat menghasilkan Rp0,69 penjualan. Pada tahun 2011 total assets turnover atau perputaran aktiva tetap PT. Telekomunikasi Indonesia (Persero) Tbk adalah 0,70 kali. Artinya setiap Rp1 aktiva tetap dapat menghasilkan Rp0,70 penjualan. Pada tahun 2012 total assets turnover atau perputaran aktiva tetap PT. Telekomunikasi Indonesia (Persero) Tbk adalah 0,69 kali. Artinya setiap Rp1 aktiva tetap dapat menghasilkan Rp0,69 penjualan. Pada tahun 2013 total assets turnover atau perputaran aktiva tetap PT. Telekomunikasi Indonesia (Persero) Tbk adalah 0,65 kali. Artinya setiap Rp1 aktiva tetap dapat menghasilkan Rp0,65 penjualan. Pada tahun 2014 total assets turnover atau perputaran aktiva tetap PT. Telekomunikasi Indonesia (Persero) Tbk adalah 0,64 kali. Artinya setiap Rp1 aktiva tetap dapat menghasilkan Rp0,64 penjualan. Pada tahun 2015 total assets turnover atau perputaran aktiva tetap PT. Telekomunikasi Indonesia (Persero) Tbk adalah 0,62 kali. Artinya setiap Rp1 aktiva tetap dapat menghasilkan Rp0,62 penjualan.

\section{B. Rasio Rentabilitas PT. Telekomunikasi Indonesia (Persero) Tbk}

Rasio rentabiltas digunakan untuk menilai kemampuan perusahaan dalam mencari keuntungan. Rasio rentabilitas juga digunakan untuk mengukur tingkat efektivitas manajemen secara keseluruhan yang ditunjukan oleh besar kecilnya tingkat keuntungan yang diperoleh dalam hubungannya dengan penjualan maupun investasi. $\mathrm{Se}^{-}$ makin tinggi rasio rentabilitas menggambarkan semakin baiknya kinerja keuangan perusahaan, begitupun sebaliknya. Dalam penelitian ini rasio rentabilitas yang digunakan meliputi tingkat pengembalian investasi (return on investment) dan tingkat pengembalian modal (return on equity).

a. Tingkat Pengembalian Investasi (Return on Investment) / ROI

Dalam mencari nilai tingkat pengembalian investasi (return on investment) data yang digunakan adalah dengan membandingkan laba setelah bunga dan pajak dengan total aktiva.

Rumus yang digunakan untuk mendapatkan nilai tingkat pengembalian (return on investment) :

\section{Return on Investment $=$}

$\underline{\text { Laba Bersih Setelah Bunga dan Pajak }}$ x 100\% Total Aktiva 


\begin{tabular}{|c|c|c|c|c|c|}
\hline \multicolumn{6}{|c|}{$\begin{array}{l}\text { Tabel 7. Komponen Return on Investment } \\
\text { PT. Telekomunikasi Indonesia (Persero) Tbk Tahun } 2007 \text { - } 2015\end{array}$} \\
\hline Tahun & $\begin{array}{l}\text { Laba Bersih } \\
\text { Setelah } \\
\text { Bunga dan } \\
\text { Pajak }\end{array}$ & Total Aktiva & $\begin{array}{l}\text { Return on } \\
\text { Investment }\end{array}$ & $\begin{array}{l}\text { Standar } \\
\text { Industri }\end{array}$ & Hasil \\
\hline 2007 & 17.669 & 82.457 & $21,43 \%$ & \multirow{9}{*}{$30 \%$} & Kurang Baik \\
\hline 2008 & 14.671 & 91.355 & $16,06 \%$ & & Kurang Baik \\
\hline 2009 & 15.977 & 98.056 & $16,29 \%$ & & Kurang Baik \\
\hline 2010 & 15.936 & 100.501 & $15,86 \%$ & & Kurang Baik \\
\hline 2011 & 14.394 & 103.054 & $13,97 \%$ & & Kurang Baik \\
\hline 2012 & 18.388 & 111.369 & $16,51 \%$ & & Kurang Baik \\
\hline 2013 & 20.402 & 127.951 & $15,95 \%$ & & Kurang Baik \\
\hline 2014 & 21.471 & 140.895 & $15,24 \%$ & & Kurang Baik \\
\hline 2015 & 23.948 & 166.173 & $14,41 \%$ & & Kurang Baik \\
\hline \multicolumn{6}{|c|}{$\begin{array}{r}\text { Sumber: Laporan Keuangan PT. Telekomunikasi Indonesia (Persero) Tbk tahun 2007-2015 (Data } \\
\text { yang diolah }\end{array}$} \\
\hline
\end{tabular}

Berdasarkan perhitungan tersebut return on investment $\mathrm{PT}$. Telekomunikasi Indonesia (Persero) Tbk pada tahun 2007 sampai dengan 2015 mengalami ketidakstabilan yang artinya mengalami peningkatan dan penurunan. Hal ini disebabkan karena terjadi perubahan pada laba setelah bunga dan pajak serta total aktiva yang dimiliki perusahaan. Dimana perhitungan return on investment PT. Telekomunikasi Indonesia (Persero) Tbk pada tahun 2007 menunjukkan bahwa tingkat pengembalian investasi yang diperoleh perusahaan sebesar $21,43 \%$ dan mengalami penurunan di tahun selanjutnya yakni di tahun 2008 sebesar 16,06\%. Artinya hasil pengembalian investasi berkurang sebesar 5,37\% hal ini disebabkan karena jumlah beban usaha yang meningkat dan laba sebelum pajak penghasilan yang dipengaruhi oleh pendapatan bunga, beban bunga, dan selisih kurs. Kemudian mengalami peningkatan di tahun 2009 sebesar 16,29\%. Artinya tingkat pengembalian investasi bertambah 0,23\% hal ini disebabkan karena meningkatnya laba usaha dan laba sebelum pajak yang dipengaruhi oleh selisih kurs - bersih dan menurunnya kerugian beban bunga.

Selanjutnya pada tahun 2010 tingkat pengembalian investasi mengalami penurunan sebesar 15,86\% atau berkurang sebesar 0,43\% penyebabnya dikarenakan meningkatnya beban usaha. Kemudian mengalami penurunan kembali pada tahun 2011 sebesar 13,97\% atau berkurang sebesar 1,89\% penyebabnya dikarenakan beban usaha yang meningkat serta tidak adanya pendapatan bunga.

Kemudian pada tahun 2012 mengalami peningkatan sebesar $16,51 \%$. Artinya tingkat pengembalian investasi bertambah sebesar $2,54 \%$ selain karena total aktiva juga disebabkan oleh meningkatnya pendapatan dan penghasilan pendanaan. Namun pada tahun 2013 mengalami penurunan sebesar $15,95 \%$ atau berkurang sebesar $0,56 \%$ selain karena total aktiva yang meningkat juga disebabkan oleh meningkatnya pendapatan disertai meningkatnya beban usaha.

Selain di tahun 2013 yang telah mengalami penurunan, secara bertahap di tahun 2014 dan 2015 dimana tingkat pengembalian investasi mengalami penurunan kembali masing-masing sebesar 15,24\% dan 14,41\%, sehingga berkurang sebesar $0,71 \%$ dan $0,83 \%$ selain karena total aktiva juga karena disebabkan meningkatnya beban usaha diikuti dengan total biaya pendanaan.

b. Tingkat Pengembalian Modal (Return on Equity) / ROE

Dalam mencari nilai tingkat pengembalian modal (return on equity) data yang digunakan adalah dengan membandingkan laba setelah bunga dan pajak dengan total ekuitas.

Rumus yang digunakan untuk mendapatkan nilai tingkat pengembalian modal (return on equity):

Return on Equity =

Laba Bersih Setelah Bunga dan Pajak Total Ekuitas $\quad$ x $100 \%$

Tabel 8. Komponen Return on Equity

PT. Telekomunikasi Indonesia (Persero) Tbk Tahun 2007 - 2015

\begin{tabular}{|c|r|r|r|l|c|}
\hline Tahun & $\begin{array}{c}\text { Laba Bersih } \\
\text { Setelah } \\
\text { Bunga dan } \\
\text { Pajak }\end{array}$ & $\begin{array}{c}\text { Total } \\
\text { Ekuitas }\end{array}$ & $\begin{array}{c}\text { Return on } \\
\text { Equity }\end{array}$ & $\begin{array}{c}\text { Standar } \\
\text { Industri }\end{array}$ & Hasil \\
\hline 2007 & 17.669 & 33.748 & $52,36 \%$ & & Baik \\
\hline 2008 & 14.671 & 34.314 & $42,76 \%$ & \multirow{2}{*}{$40 \%$} & Baik \\
\hline 2009 & 15.977 & 38.990 & $40,98 \%$ & & Baik \\
\hline 2010 & 15.936 & 56.415 & $28,25 \%$ & & Kurang Baik \\
\hline
\end{tabular}




\begin{tabular}{|c|c|c|c|c|}
\hline 2011 & 14.394 & 60.981 & $23,60 \%$ & Kurang Baik \\
\hline 2012 & 18.388 & 66.500 & $27,65 \%$ & Kurang Baik \\
\hline 2013 & 20.402 & 77.424 & $26,35 \%$ & Kurang Baik \\
\hline 2014 & 21.471 & 86.125 & $24,93 \%$ & Kurang Baik \\
\hline 2015 & 23.948 & 93.428 & $25,63 \%$ & Kurang Baik \\
\hline
\end{tabular}

Berdasarkan perhitungan antara perbandingan laba bersih setelah bunga dan pajak dengan total ekuitas (modal) didapatkan hasil tersebut yaitu tingkat pengembalian modal (return on equity) PT. Telekomunikasi Indonesia (Persero) Tbk pada tahun 2007 sampai dengan 2015 mengalami ketidakstabilan yang artinya mengalami peningkatan dan penurunan. Hal ini disebabkan karena terjadi perubahan pada laba setelah bunga dan pajak serta total ekuitas yang dimiliki perusahaan. Dimana pada tahun 2007 menunjukkan bahwa tingkat pengembalian modal sebesar $52,36 \%$ dan pada tahun selanjutnya mengalami penurunan secara bertahap selama 4 (empat) tahun ditahun 2008, 2009, 2010, dan 2011 dimana tingkat pengembalian investasi masing-masing sebesar $42,76 \%, 40,98 \%, 28,25 \%$, dan $23,60 \%$. Artinya tingkat pengembalian modal berkurang sebesar $9,6 \%, 1,78 \%, 12,73 \%$, dan $4,65 \%$.

Selain karena laba bersih setelah bunga dan pajak dan total ekuitas, hal ini juga disebabkan karena meningkatnya beban usaha, pendapatan, selisih kurs, saldo laba, jumlah ekuitas yang dapat diatribusikan, dan menurunnya modal saham yang diperoleh kembali.

Kemudian pada tahun 2012 meningkat sebesar $27,65 \%$. Artinya tingkat pengembalian modal bertambah sebesar $4,05 \%$ hal ini disebabkan oleh meningkatnya pendapatan dan beban usaha, serta saldo laba. Setelah itu mengalami penurunan kembali secara bertahap pada tahun 2013 dan 2014 masing-masing sebesar $26,35 \%$ dan $24,93 \%$ atau berkurang sebesar 1,3\% dan 1,42\% hal ini disebabkan karena meningkatnya pendapatan, beban usaha, selisih kurs.
Selanjutnya di tahun 2015 mengalami peningkatan sebesar $25,63 \%$. Artinya tingkat pengembalian modal bertambah sebesar $0,7 \%$, selain karena laba bersih setelah bunga dan pajak serta total ekuitas yang meningkat, hal ini penyebabnya juga karena meningkatnya pendapatan, beban usaha, saldo laba, dan jumlah ekuitas yang dapat diatribusikan kepada pemilik entitas induk bersih, dan kepentingan nonpengendali.

\section{Kinerja Keuangan PT Telekomunikasi Indonesia (Persero) Tbk}

Untuk mengetahui kinerja keuangan perusahaan atau tingkat kesehatan keuangan perusahaan PT Telekomunikasi Indonesia (Persero) Tbk berdasarkan hasil perhitungan rasio aktivitas dan rasio rentabilitas yang diperoleh dari laporan keuangan perusahaan selama 9 (sembilan) tahun terhitung mulai tahun 2007 sampai dengan tahun 2015.

a. Rasio Aktivitas

\begin{tabular}{|c|c|c|c|c|}
\hline \multicolumn{5}{|c|}{$\begin{array}{l}\text { Tabel 9. Hasil Perhitungan Rasio Aktivas } \\
\text { PT Telekomunikasi Indonesia (Persero) Tbk Tahun } 2007 \text { - } 2015\end{array}$} \\
\hline Rasio & \multicolumn{4}{|c|}{ Aktivitas } \\
\hline Alat Ukur & \multicolumn{2}{|c|}{ Fixed Assets Turnover } & \multicolumn{2}{|c|}{ Total Assets Turnover } \\
\hline $\begin{array}{l}\text { Standar } \\
\text { Industri }\end{array}$ & \multicolumn{2}{|c|}{5 Kali } & \multicolumn{2}{|c|}{2 Kali } \\
\hline Tahun & Nilai & Hasil & Nilai & Hasil \\
\hline 2007 & 0,89 Kali & Kurang Baik & 0,72 Kali & Kurang Baik \\
\hline 2008 & 0,79 Kali & Kurang Baik & 0,66 Kali & Kurang Baik \\
\hline 2009 & 0,79 Kali & Kurang Baik & 0,66 Kali & Kurang Baik \\
\hline 2010 & 0,85 Kali & Kurang Baik & 0,69 Kali & Kurang Baik \\
\hline 2011 & 0,88 Kali & Kurang Baik & 0,70 Kali & Kurang Baik \\
\hline 2012 & 0,93 Kali & Kurang Baik & 0,69 Kali & Kurang Baik \\
\hline 2013 & 0,87 Kali & Kurang Baik & 0,65 Kali & Kurang Baik \\
\hline 2014 & 0,84 Kali & Kurang Baik & 0,64 Kali & Kurang Baik \\
\hline 2015 & 0,87 Kali & Kurang Baik & 0,62 Kali & Kurang Baik \\
\hline Rata-Rata & 0,86 Kali & Kurang Baik & 0,67 Kali & Kurang Baik \\
\hline Sumber: & Keuangan & komunikasi Ind & (Persero) Tbk & $\begin{array}{r}\text { 2007-2015 (Data } \\
\text { yang diolah }\end{array}$ \\
\hline
\end{tabular}

Rasio aktivitas dilihat dari tingkat pengembalian aktiva tetap (fixed assets turnover) dan tingkat pengembalian total aktiva (total assets turnover) selama 9 (sembilan) tahun dari tahun 2007 sampai dengan 2015 hasil analisis diatas dapat disimpulkan bahwa perusahaan belum bisa memaksimalkan perputaran aktiva tetap dan tidak mampu 
mencapai standar industri masih berada dibawah standar yang sudah ditetapkan. Ini dikarenakan setiap tahunnya untuk total aktiva tetap maupun total aktiva lebih besar nilainya dibandingkan dengan penjualan meskipun setiap tahunnya terus menerus mengalami peningkatan. Perusahaan diharapkan meningkatkan lagi penjualannya atau mengurangi sebagian aktiva yang kurang produktif.

b. Rasio Rentabilitas

\begin{tabular}{|c|c|c|c|c|}
\hline \multicolumn{5}{|c|}{$\begin{array}{l}\text { Tabel 10. Hasil Perhitungan Rasio Rentabilitas } \\
\text { PT Telekomunikasi Indonesia (Persero) Tbk Tahun } 2007 \text { - } 2015\end{array}$} \\
\hline Rasio & \multicolumn{4}{|c|}{ Aktivitas } \\
\hline Alat Ukur & \multicolumn{2}{|c|}{ Return on Investment } & \multicolumn{2}{|c|}{ Return on Equity } \\
\hline $\begin{array}{l}\text { Standar } \\
\text { Industri }\end{array}$ & \multicolumn{2}{|c|}{$30 \%$} & \multicolumn{2}{|c|}{$40 \%$} \\
\hline Tahun & Nilai & Hasil & Nilai & Hasil \\
\hline 2007 & $21.43 \%$ & Kurang Baik & $52.36 \%$ & Baik \\
\hline 2008 & $16.06 \%$ & Kurang Baik & $42.76 \%$ & Baik \\
\hline 2009 & $16.29 \%$ & Kurang Baik & $40.98 \%$ & Baik \\
\hline 2010 & $15.86 \%$ & Kurang Baik & $28.25 \%$ & Kurang Baik \\
\hline 2011 & $13.97 \%$ & Kurang Baik & $23.60 \%$ & Kurang Baik \\
\hline 2012 & $16.51 \%$ & Kurang Baik & $27.65 \%$ & Kurang Baik \\
\hline 2013 & $15.95 \%$ & Kurang Baik & $26.35 \%$ & Kurang Baik \\
\hline 2014 & $15.24 \%$ & Kurang Baik & $24.93 \%$ & Kurang Baik \\
\hline 2015 & $14.41 \%$ & Kurang Baik & $25.63 \%$ & Kurang Baik \\
\hline Rata-Rata & $16.19 \%$ & Kurang Baik & $32.50 \%$ & Kurang Baik \\
\hline Sumber: & & omunikasi Ind & rsero) Tbk & $\begin{array}{l}2007-2015 \text { (Dat } \\
\text { yang diolal }\end{array}$ \\
\hline
\end{tabular}

Berdasarkan hasil data yang dianalisis tersebut dapat diukurlah kinerja keuangan dari rasio rentabilitas berdasarkan standar industri yang sudah ditetapkan yaitu ratarata rasio rentabilitas PT. Telekomunikasi Indonesia (Persero) Tbk selama 11 (sebelas) tahun terakhir masuk kedalam kategori "Kurang Sehat", dikarenakan rata-rata rasio rentabilitas PT. Telekomunikasi Indonesia (Persero) Tbk berdasarkan perhitungan return on investment hasilnya masih dibawah standar industri $(<30 \%)$ dan return on equity masih di bawah standar industry $(<40 \%)$.

\section{SIMPULAN}

Rasio Aktivitas PT. Telekomunikasi Indonesia (Persero) Tbk periode 2007 sampai dengan 2015 yang terdiri atas fixed assets turnover dan total assets turnover mengalami ketidakstabilan yang artinya adanya peningkatan dan penurunan di setiap tahunnya.

Sedangkan rata-rata fixed assets turnover pada tahun 2007 sampai dengan 2015 ialah sebesar 0,86 Kali ( $<5 \mathrm{Kali})$, dan dari total assets turnover yaitu sebesar 0,67 Kali $(<2$ Kali), yang artinya kinerja keuangan PT. Telekomunikasi Indonesia (Persero) Tbk pada Rasio Aktivitas dalam keadaan kurang baik.

Rasio Rentabilitas PT. Telekomunikasi Indonesia (Persero) Tbk periode 2007 sampai dengan 2015 yang terdiri atas return on investment dan return on equity pada tahun 2007 sampai dengan 2015 cenderung mengalami ketidakstabilan yang artinya adanya peningkatan dan penurunan di setiap tahunnya.

Sedangkan berdasarkan total rata-rata return on investment yaitu sebesar $16.19 \%(<30 \%)$ dan total rata-rata return on equity yaitu sebesar $32.50 \%$ (< 40\%), yang artinya kinerja keuangan PT. Telekomunikasi Indonesia (Persero) Tbk pada rasio rentabilitas dalam keadaan kurang baik.

Kinerja keuangan perusahaan dikatakan baik jika mampu mencapai standar industri yang telah ditetapkan yaitu 30\% untuk return on investment dan $40 \%$ untuk return on equity. Dengan kondisi kinerja perusahaan kurang baik, perusahaan dikatakan belum mampu menghasilkan keuntungan yang maksimal karena kinerja keuangan perusahaan kurang baik.

Berdasarkan hasil analisis penilaian kinerja dari aspek keuangan perusahaan selama sembilan tahun untuk rasio aktivitas dan rasio rentabilitas PT. Telekomunikasi Indonesia (Persero) Tbk dapat dikatakan kurang baik. Hal ini bisa dilihat dari aktivitas perusahaan rata-rata fixed assets turnover 0,86 Kali ( $<5$ Kali standar industri) dan total assets turnover 0,67 Kali $(<2$ Kali standar industri) dan return on investment $16.19 \%(<30 \%$ standar industri) dan return on equty $32.50 \%$ ( $<40 \%$ standar industri), maka dapat dikatakan perusahaan belum mampu menghasilkan keuntungan yang maksimal. 


\section{DAFTAR PUSTAKA}

Harjito, A., \& Martono. (2014). Manajemen Keuangan, Edisi Kedua, Cetakan Pertama. Yogyakarta: Penerbit Ekonisia.

Keown, A. J., dkk. (2010). Dasar-dasar Manajemen Keuangan. Jakarta: Salemba Empat.

Fahmi, I. (2012). Analisis Laporan Keuangan, Cetakan Ke-2. Bandung: Alfabeta.

Fahmi, I. (2014). Analisis Laporan Keuangan. Bandung: Alfabeta.

Fahmi, I. (2016). Manajemen Sumber Daya Manusia Teori dan Aplikasi. Bandung: CV Alfabeta.

Gitosudarmo, I., \& Basri. (2010). Manajemen Keuangan, Edisi Keempat, Cetakan Pertama. Yogyakarta: Penerbit BPFE.

Harahap, S. S., (2015). Analisis Kritis Atas Laporan Keuangan. Jakarta: Rajawali Persada.

Hasibuan, M. (2016). Manajemen, Dasar, Pengertian, dan Masalah. Jakarta: Bumi Akasara.

Hery, S.E., M.Si., CRP., RSA, (2016). Analisis Laporan Keuangan, Integrated and Compherensive Edition. Jakarta: PT. Grasindo Anggota IKAPI.

James C. van Horne \& John M. Wachowicz jr, (2012). Prinsip-prinsip Manajemen Keuangan, Edisi 13, Buku 1. Jakarta: Salemba Empat.

Kasmir, (2012). Analisis Laporan Keuangan, Cetakan keenam. Jakarta: PT. Raja Grafindo Persada.

Kasmir, (2013). Analisis Laporan Keuangan. Jakarta: Rajawali Persada.

Martono., \& Agus Harjito, (2010). Manajemen Keuangan, Cetakan Kedelapan. Yogyakarta: Penerbit Ekonisia.

Munawir, S. (2010). Analisis Laporan Keuangan, Edisi Keempat. Cetakan Kelima Belas. Yogyakarta: Liberty.

Munawir, S. (2014). Analisis Laporan Keuangan. Yogyakarta: Liberty.

Riyanto, B. (2010). Dasar-dasar Pembelanjaan Perusahaan. Yogyakarta: BPFE

Sartono, A. (2010). Manajemen Keuangan Teori dan Aplikasi, Edisi Keempat, Cetakan Keempat. Yogyakarta: Penerbit BPFE

Sawir, A. (2013). Analisis Kinerja Keuangan dan Perencanaan Keuangan Perusahaan, Cetakan kedua. Jakarta: Penerbit PT. Gramedia Pustaka Utama.

Solihin, I. (2012). Manajemen Strategik. Jakarta: Penerbit Erlangga.

Sugiyono, (2010). Metode Penelitian Pendidikan Pendekatan Kuantitatif, Kualitatif dan R\&D. Bandung: Alfabeta.

Sugiyono, (2014). Memahami Penelitian Kualitatif, Dilengkapi Contoh Proposal dan Laporan Penelitian. Bandung: Alfabeta.

Sugiyono, (2016). Memahami Penelitian Kualitatif dan Kombinasi (Mixed Methods). Bandung: Alfabeta.

Sutrisno, (2010). Manajemen Keuangan, Teori, Konsep dan Aplikasi, Edisi Pertama, Cetakan Ketiga. Yogyakarta: Penerbit Ekonisia.

Suharsaputra, U. (2014). Metode Penelitian Kuantitatif, Kualitatif dan Tindakan. Bandung: PT. RefikaAditama.

Hartono, E., P. (2017). Analisis Rasio Likuiditas, Aktivitas dan Profitabilitas Untuk Menilai Kinerja Keuangan Pada PT. Sumber Alfaria Trijaya, Tbk (Periode 2011-2015). Tangerang Selatan: Universitas Pamulang.

Nurhidayah, M. (2018). Analisis Rasio Likuiditas dan Solvabilitas Untuk Menilai Kinerja Keuangan Pada PT. Telekomunikasi Indonesia, Tbk Periode Tahun (2011-2015). Tangerang Selatan: Universitas Pamulang.

Seviyantas., M., K. (2017). Analisis Rasio Aktivitas dan Profitabilitas Guna Menilai Kinerja Keuangan Pada Gajah Tunggal Tbk. Tangerang Selatan: Universitas Pamulang.

Ermayanti, D. (2009). Kinerja Keuangan Perusahaan. Diakses 1 November 2018 darihttps:// dwiermayanti.wordpress.com/2009/10/15/ kinerja-keuangan-perusahaan/. 